\title{
Lectures as a symbiosis of scientific- methodological and practice-oriented personal development technologies
}

\author{
S.M. Kurbatova ${ }^{1,2,3^{*}}$, L.Yu. Aisner ${ }^{1}, A . G$. Rusakov $^{1}$, and V.V. Naumkina ${ }^{4}$ \\ ${ }^{1}$ Krasnoyarsk State Agrarian University, 90 Mira Av., Krasnoyarsk, 660042, Russia \\ ${ }^{2}$ Saint-Petersburg University of Management Technologies and Economics, 44 Lermontovsky Av., \\ Saint Petersburg, 190103, Russia \\ ${ }^{3}$ Krasnoyarsk state medical University named after Prof. V. F. Voino-Yasenetsky, 1 Partisan \\ Zheleznyak Av., Krasnoyarsk, 660022, Russia \\ ${ }^{4}$ Khakass State University, 90, Lenin Ave., Abakan, the Republic of Khakassia, 655000, Russia
}

\begin{abstract}
The model of a modern University is characterized by the formalization of its activities within the framework of implementing specific educational programs through the educational process and focusing on the final result in the form of a competitive specialist. As a result, the universal values, the spirit of participation in the acquisition of new knowledge, which were present in previous generations of universities, are leveled. However, the students' needs in their personal development remain at the present time. This leads to the search for new forms and the use of new technologies to meet this need. Based on the research, the authors propose a Lectures model as one of these forms, which includes scientific and methodological, practice-oriented and personal-development components. This is where the spirit of the University as an element of Higher education, the tasks of the University as an educational organization to train competitive specialists and the needs of the individual in self-development can be realized. Considering the development of information and educational technologies, it is necessary to apply them actively in the already available instruments of the Higher School. The educational process should become interesting, interactive, covering various aspects of the studied disciplines as much as possible. But at the same time, the educational process should not lose its main purpose - the formation of new knowledge and the upbringing of a socially active and positive personality. Taking into account the development of science and technology it is these two components that the Lectures are directed towards.
\end{abstract}

* Corresponding author: sveta_kurbatova@mail.ru 


\section{Introduction}

Modern universities are radically different from their predecessors [1, 2], which is a natural process [3], reflecting the features of the historical evolution of the society and the state and the trends that have emerged as a result of this in pedagogy and education [4].

But "if previously knowledge and science were based on an enlightening picture of the world and were considered mainly as an absolute and boundless value, now the concept of useful knowledge prevailed, i.e. knowledge that is essentially limited, focused on specifics and aimed at a result that brings immediate economic benefits. From now on, the University is not a temple of science, but a "market place" in the broadest sense [5]. This is the result of changes that have taken place in societies and states over the past decades, and in which, it should be noted, universities-organizations themselves have taken an active part. We are talking about scientific and technical development, new innovative methods and technologies [6], the development of the globalization process and integration into the world community, etc. [7]. All this leads to the "search for parameters that determine the specificity of the modern educational space of the University, in particular, the modern University" [8]. Although their essence has not changed: universities still carry out not only training, but also conduct research.

In this regard, "the assumption seems quite justified that changing in accordance with the spirit of the epoch, the modern University can and should be considered not only in the aspect of economic viability, but also from the standpoint of anthropological perspectives of the formation of the future society, generating appropriate responses to the postmodern challenges" [9], contributing to the solution of socio-cultural personal identification [10].

Therefore, the authors of the article distinguish between the concepts of "University" as an educational organization of higher education that provides educational services and "University" as a special structure of society for the systematic accumulation and transfer of knowledge from generation to generation, reflecting the deep philosophical meaning of the term "Higher school". Accordingly, in the opinion of the authors, it is necessary to distinguish between the concept of "pedagogical technologies" used at universities and "Higher school technologies".

\section{Purpose and objectives of the research}

The aim of the research is to study the issues of improving the educational process quality in higher educational institutions through the use of educational technologies, based on the symbiosis of scientific and practice-oriented activities. For this purpose the authors propose to consider the Lecture format as such an educational technology. The authors of this form base on the understanding that at present the education system reflects a new approach to realizing its essence and shifting its center towards the student, with all the ensuing consequences. Accordingly, the learning process should become interesting, interactive, maximally covering various aspects of the studied disciplines. But at the same time, the educational process should not lose its main purpose - the formation of new knowledge and the upbringing of a socially active and positive personality. This is exactly what the Lecture format proposed by the authors will contribute to.

The objectives of the study are:

- understanding the essence of pedagogical technologies;

- identification of their most important characteristics and features of their application in the Higher School;

- disclosure of the elements of pedagogical technologies on the example of a specific scientific and methodological model of interdisciplinary nature: Higher School Lectures. 


\section{Methods}

The study was carried out on the basis of general scientific methods, through the study of information sources and their analysis, sociological observation of the use of various pedagogical technologies at the Higher School, a survey of students and their teachers, and analysis of the received information. All this contributed to the formation of certain conclusions and contributed to the modeling of the proposed educational technology, based on scientific methods of synthesis and modeling. The result of the study will also be the introduction of the proposed model into the activities of the institute, where three authors of this article work. From September 2020, the Interdepartmental Scientific and Methodological Lectures for students of the Law Institute of Krasnoyarsk State Agrarian University will begin their work.

\section{Pedagogical technologies}

There is no single concept of what pedagogical technologies represent. But in general, we can note that they are oriented to the understanding of the University as an organization that carries out educational activities under current law and for the enforcement thereof.

Thus, different authors understand pedagogical technologies as means, methods, materials, equipment, etc., which is aimed at 1) the educational process; 2) the teacher and the student (table 1).

Table 1.

\begin{tabular}{|c|c|c|}
\hline Authors & Definition \\
\hline V. P. Bespalko [11] & $\begin{array}{c}\text { A set of means and methods of reproduction theoretically substantiated } \\
\text { processes of training and education that enable successful implementation of } \\
\text { the set educational goals }\end{array}$ \\
\hline S. I. Zmeev [12] & $\begin{array}{c}\text { Organization of the learning process, which provides a certain system of } \\
\text { action and interaction of everything, but primarily active elements of the } \\
\text { learning process }\end{array}$ \\
\hline V. S. Kukushin [13] & $\begin{array}{c}\text { A set of methods and tools for processing, presenting, changing, and } \\
\text { producing educational information. In the technology of training, the } \\
\text { content, methods and means of training are interrelated and mutually } \\
\text { dependent }\end{array}$ \\
\hline F. Coombs [14] & $\begin{array}{c}\text { A wide variety of methods, materials, equipment and supply systems - } \\
\text { everything that is involved in the educational process and contributes to the } \\
\text { work of the educational system }\end{array}$ \\
\hline M. M. Levina [15] & $\begin{array}{c}\text { Learning technology is a didactic construction of information management } \\
\text { of educational and cognitive activity of students, reflecting the regularities } \\
\text { of educational knowledge }\end{array}$ \\
\hline $\begin{array}{c}\text { V. M. Monakhov [16] } \\
\text { This is a well-thought-out model of joint pedagogical activity for the design, } \\
\text { organization and conduct of the educational process with the indisputable } \\
\text { provision of comfortable conditions for students and teachers }\end{array}$ \\
\hline $\begin{array}{c}\text { Harris, J., \& Hofer, } \\
\text { M. [17] }\end{array}$ & $\begin{array}{c}\text { Curriculum-based technology integration, which is based on combining } \\
\text { technologically supported types of learning activities within taxonomies of } \\
\text { activity types with learning content }\end{array}$ \\
\hline $\begin{array}{c}\text { Scott, P. \& Jewitt, C. } \\
\text { [18] }\end{array}$ & \begin{tabular}{c} 
Talk, action and visual communication in teaching and learning science \\
\hline
\end{tabular} \\
\hline
\end{tabular}

At the same time the technologies themselves are: personality-oriented technology of training; technology of collective learning; the technology of sign and contextual learning; game technologies in educational process of Higher school; computer technology training; subject-oriented technology of training; the technology of complete knowledge acquisition; 
the technology of level differentiation; the technology of concentrated training; the technology of creating a "cheat sheet"; activity learning technologies: simulation of professional activity in educational process of the University; the technology of modular training; the technology of problem-based modular training; a project method; search and research technology of training; pedagogical technology of heuristic type; reflection and improvisation as a pedagogical technology [19].

In relation to these technologies, it is necessary to take into account the current expectations of universities, which determine the setting of tasks for them. And one of the main tasks is to bring the results of their activities closer to the needs of life, creating conditions for the purposeful formation of competitive specialists. Modern society creates a social need for a generation that can live and develop in the space of knowledge-intensive, information-rich technologies; it requires the development of the ability to navigate and act in the constantly changing world of production, business, and socio-political life. In such a society, the transition from fundamental knowledge to innovation and the provision of specialist training for specific work is of great importance [20].

This is facilitated by pedagogical technologies, which are filled with different content depending on the field of the University (technical, technological, medical, humanitarian, etc.) and a specific educational program. The result of this program, in the process of providing educational services by the University to its students, is the acquisition of different types and levels of competencies aimed at the final product of this educational activity in the form of training competitive specialists in a specific field.

\section{Higher school technologies}

These technologies have a broader meaning and, what is very important, purpose, in comparison with pedagogical technologies, despite the fact that they partially overlap, since both of them are United by what, or more precisely, who they are aimed at - the student.

Higher school technologies are based on the meaning of the term "Higher school" ("University»):

1) "this is a corporation of intellectuals who serve scientific truth, objective knowledge and common interests, and not some parties, political groups, or political ideology;

2 ) it is a community of scientists and simply educated people who think and evaluate the processes and events taking place in society not from the point of view of the interests of a particular social group or political grouping, but from the point of view of the interests of man and humanity" [21].

The purpose of Universities is to have an evolutionary impact on society and the state as a whole, through educational, cultural and scientific processes that affect each individual student, contributing to their comprehensive development, strengthening social cohesion and ensuring competitive positions [22]. At the same time they are realistic enough to understand the expectations that are placed on them by the society and state, and reflect this understanding in their activities. All this brings the tasks (and therefore types) of these technologies to the level from just a university to the University level.

Understanding this, the team of authors set this postulate as a task for conducting research, during which a large volume of special literature was studied, surveys of students and teachers from different universities were conducted, which resulted in the following conclusions:

- ideas about the essence of universities as Universities remain, which causes $75-87 \%$ of students to desire to be involved in it and from 88 to $94 \%$ of teachers to be involved in its implementation - in different forms, using different technologies. At the same time the majority noted as a necessary condition to reduce the bureaucratic requirements that abound 
in the modern educational system in Russia, to free up some of their time for these purposes;

- both students (96\%) and teachers perceive the University as something more than just an organization that provides services to consumers and provides work to employees $(94 \%)$;

- the main forms of the educational process organization (lectures and practical classes, independent students work, consultations, etc.) are aimed at the implementation of educational activities as a specific service. The types, duration, content, etc. of this service are determined by legislation and detailed by local regulations of universities. This is not enough to implement the initial ideas of what a University and Higher school are $(63 \%$ of the surveyed students, although some of the respondents noted that it is difficult to answer, because they do not have a clear understanding of what exactly it might be, or that just "something was missing" or that "something more was expected");

- $82 \%$ of the surveyed students expressed their desire to participate in the spirit of Higher education by participating in various events using Higher school technologies (although some of them noted that it was important for them that it was interesting, that it was not mandatory and that it did not end with any form of control - surveys, tests, etc., that is, it did not merge with the educational process).

As a result of the obtained data analysis, the authors developed the following model for reflecting the essence and spirit of Higher education, which was collectively called "the Lectures".

\section{Technologies of Higher school on the example of a model of scientific and methodological interdisciplinary Lectures of University's structural divisions (institutes)}

After discussing the obtained data at round tables, conferences, meetings, a number of conclusions and decisions were made:

1) There is a need for a structure that would accumulate the ideas of a Higher school and the tasks of a modern University, and which is called "the Lectures".

Structurally, the authors see this as follows (Fig. 1).
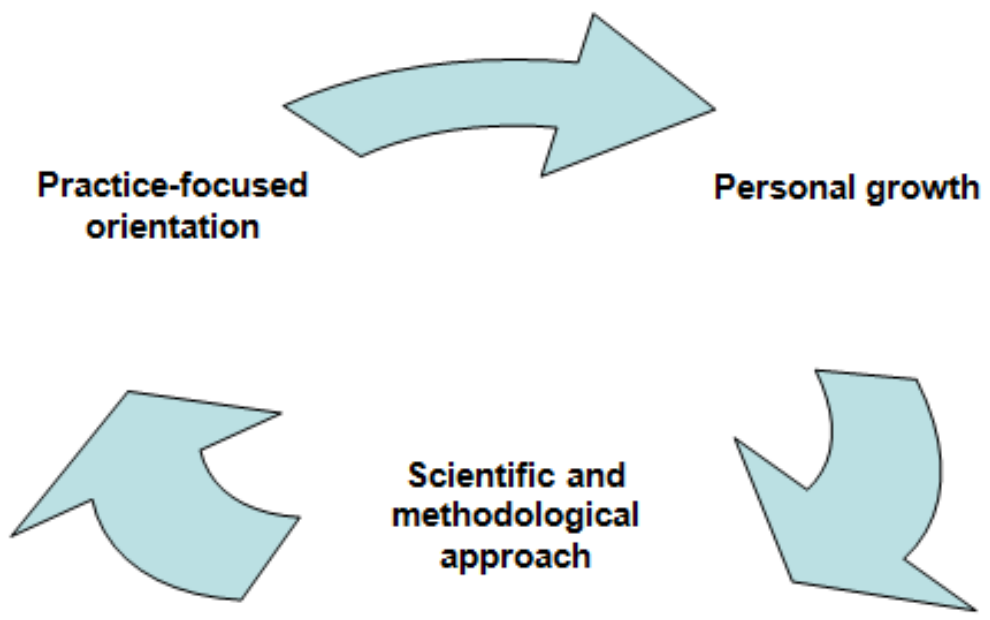

Fig. 1. Essential elements of the Lectures. 
The selection of these very components is determined by the essence of the Lectures as an interdisciplinary structure designed to establish various forms of interaction between its members, based on scientific and methodological concepts and developments, having a practice-focused orientation and contributing to the development of personal characteristics.

The scientific and methodological approach is:

- justification of the activity of the Lectures and its parts on a specific topic, for solving general and specific goals and tasks, aimed at achieving the maximum result with the highest degree of efficiency;

- formation of separate directions of its activity and understanding their expected results;

- mastering the system-based, conceptual vision of situations and processes in a specific area;

- introduction of students to the problem field of modern science, development of research skills in solving a specific task and finding solutions to identified problems;

- improving the skills of working with theoretical and methodological sources; and others [23].

Practice-focused orientation:

- deepening knowledge of individual disciplines studied within a specific educational program through interdisciplinary connections and interactions;

- getting new knowledge in related and other areas;

- mastering the skills to apply the acquired knowledge;

- orientation to the actual practice needs; etc. [24].

Personal growth is an integral attribute of Higher school and University and the educational process itself [25] and represents social, individual and spiritual growth [26], which strives for the maximum and multidimensional development of the student's personality:

- development of their potential;

- getting rid of complexes and negative character traits;

- victory over various forms of fear;

- openness to new information acceptance;

- constant readiness for action and internal transformation; etc.

The trinity of these essential elements of the Lectures allows us to strive to achieve the unity of assimilation and main values: universal, state, social, and personal [27].

2) The Lectures should be established at the level of an individual structural unit of a university (institute) to reflect its specificity. The activity of the Lectures should be comprehensible to its members, consistent with the peculiarities of the educational process of this institution, and the results could be exploited for its efficacy and development;

3) The subject of the Lectures should be broad, complex, interdisciplinary and multifaceted in order to ensure the maximum involvement of interested teachers, students and other persons. It should also facilitate the establishment of inter-institute relations within the university and interaction with other universities, while keeping in mind the specifics of the university and the region. For example, for an agricultural university, ecology [28] and related issues [29], agriculture and agribusiness [30], food security [31], sustainable rural development [32], etc. may become such topics.

4) When creating it, an integrated approach visually presented in figure 2 should be used. 


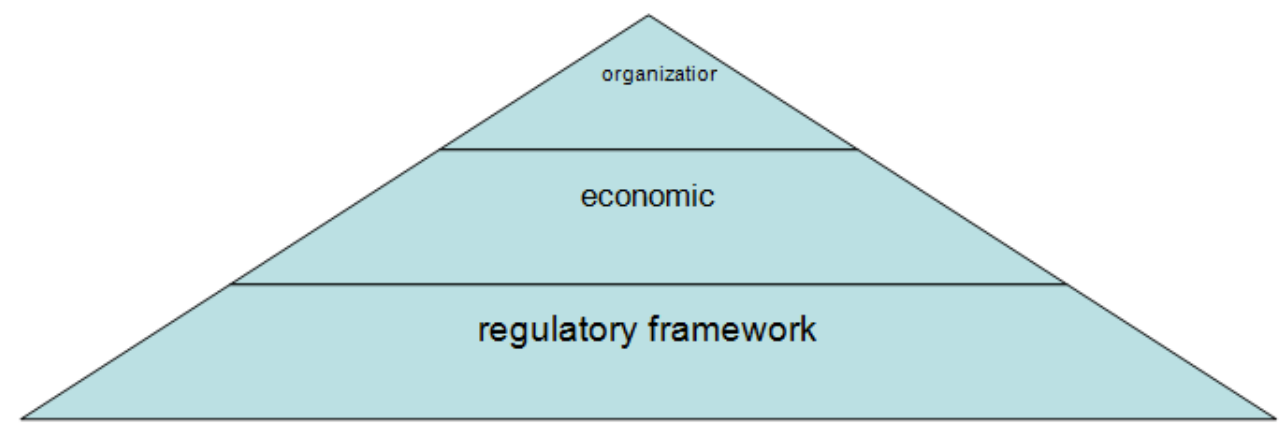

Fig. 2. The basics of the Lectures.

We will reveal their content separately, but taking into account that the proposed integrated approach provides for their unity both in their formation and in their implementation in the activities of particular Lectures.

- Regulatory framework:

- determines the place of the Lectures in the structure of the Institute and University;

- forms legal methods of its activities;

- determines the control and accountability of this structure.

- Economic basis:

- decides on the forms of financial support for the activities of the Lectures, which can be: material and monetary support from the University, participation of the Lectures members in the grant activities, the patenting of research results and intellectual work, charity, etc.;

- identifies opportunities of participation within the Lectures (its groups) to ensure the financial stability of the University through involvement in economic-contractual relations, taking into account the specifics of the University and the Lectures.

- Organizational basis:

- formation of the main team of organizers and performers;

- setting goals and objectives;

- the choice of a topic to work on;

- development of tactics and activities;

- study of similar organizational structures of other universities to use positive experience.

4) the subjects of the Lectures are:

- students;

- representatives of the teaching and administrative staff of the University;

- other persons (invited guests, students from other universities, etc.).

5) The forms of the Lectures activity are:

- holding scheduled and unscheduled meetings on specific issues to discuss, analyze, pose problems and find solutions to them; aspect;

- work of individual study groups on a specific topic, but with an interdisciplinary

- inviting well-known scientists, including visiting professors, to speak on certain topics of the Lectures;

- participation of representatives of the practical sphere to establish clear links between the needs of practice and the capabilities of the scientific community in their provision and the formation of students' practical skills; 
- participation in the implementation of the Institute / University tasks, grant and other project activities that require a symbiosis of scientific and methodological base and practical skills and affect the development of personal characteristics;

- organization and participation in scientific and practical events (conferences, round tables, symposiums, etc.), with the involvement of guests from other universities, including foreign ones, authorities and organizations;

- using the results of the Lectures participation in the educational process (in practical and seminar classes, when writing tests, term papers, final qualifying and other works, when having practical training, taking exams, including final certification, etc.).

\section{Conclusions}

Despite the fact that at present, in relation to universities, a specific result rather than the achievement of common goals comes to the fore, practical competencies rather than high universal and social values are formed, not education as such but the educational process is carried out, the essence of Higher education within the University is still preserved, as evidenced by the wishes of students and the readiness of teachers. And this is a clear reflection of the action of the dialectics laws: the unity and struggle of opposites; the transition of quantity into quality; the negation of negation.

Their implementation determines the development of matter, spirit, consciousness, knowledge and other aspects of reality, based on the principles of universal connection, systematicity, causality and historicism.

Within the framework of this study, in the context of analyzing changes in the understanding of the essence of the University, it is noted that the formalization of the educational process, which is a legally regulated and methodically ordered activity for providing educational services to obtain a specific result represented by a competitive specialist, often levels the University values that were previously present in it. However, the need for personal development inherent in a person [33] manifests itself. This necessitates the search for new forms and the use of new technologies to ensure it.

One of these forms was designed by the authors as a model of the Lectures, as a trinity of scientific-methodological and practice-oriented foundations that ensure the personal development of students.

The research results will be applied directly into practice. From September 2020, the proposed model of Lectures will begin to be implemented at the institute, where three authors of this article work. It will be the Interdepartmental Scientific and Methodological Lectures for Students of the Law Institute of Krasnoyarsk State Agrarian University.

\section{References}

1. L. L. Rodina, N. V. Nikolaeva, A. I. Ponomarev, From the history of universities, Bulletin of Saint Petersburg University. Ser. 4. Vol. 2 (60). Issue 405-423 (2015)

2. V. V. Ryapolov, The emergence of medieval universities: content and forms of education, Business and design review 1 (9) 15 (2018)

3. M. P. Vatsenko, T. V. Melnikova, A. V. Leopa, A. N. Gorodishcheva, S. P. Stumpf, D. V. Rakhinsky, Sustainable development and perspectives of universalistic trends in the modern world. Revista inclusiones vol 73 212-222 (2020)

4. A. G. Kislov, O. V. Shmurygina, The Idea of the University: a retrospective, versions and perspectives 8 (97) 96-122 (2012) 
5. N. E. Pokrovsky, Transformation of universities in the conditions of the global market, Journal of sociology and social anthropology, vol. 74 152-161 (2004)

6. J. H. L. Koh, C. S. Chai, Teacher clusters and their perceptions of technological pedagogical content knowledge (TPACK) development through ICT lesson design. Computers \& Education 70 222-232 (2014)

7. R. Pringle, K. Dawson, A. Ritzhaupt, Integrating science and technology: Using technological pedagogical content knowledge as a framework to study the practices of science teachers. Journal of Science Education and Technology 24 648-662 (2015)

8. A. A. Rusanova, Transformation of the University in innovative processes of the Institute of higher education, Historical and socio-educational thought 4 88-92 (2011)

9. L. Yu. Aisner, O. D. Naumov, Anthropological practices of the modern University: on the issue of "self-care" in the conditions of the fourth industrial revolution, Collection of scientific papers of the 6th International scientific and practical conference: Cluster initiatives in the formation of a progressive structure of the national economy and Finance. Southwestern state University. Kursk, 10-13 (2020)

10. I. A. Pfanenshtil, M. P. Yatsenko, V. I. Kudashov, A. L. Mongush, D.V. Rakhinsky, Multiculturalism and educational practice: problems of socio-cultural identity preservation. In the conference proceedings: The European Proceedings of Social \& Behavioural Sciences EpSBS Conference: SCTCGM 2018 - Social and Cultural Transformations in the Context of Modern Globalism 1493-1502 (2019)

11. Sh. A. Amonashvili, V. F. Shatalov, S. N. Lysenkova, Pedagogical encyclopedia. Krasnodar, 18-41 (1989)

12. S. I. Zmeev, Technology of adult education, Moscow: Academia, 16-17 (2002)

13. Pedagogical technologies ed. by V. S. Kukushkin, Moscow, Rostov n / D, Phoenix, 5 (2006)

14. F. Coombs, Crisis of education in the modern world, Moscow, Progress 130 (1970)

15. M. M. Levina, Technologies of professional pedagogical education, Moscow, Academia, 14-15 (2001)

16. Sh. A. Amonashvili, V. F. Shatalov, S. N. Lysenkova, Pedagogical encyclopedia, Krasnodar, 126 (1989)

17. J. Harris, M. Hofer, Instructional planning activity types as vehicles for curriculumbased TPACK development. In C. Maddux (Ed.), Research highlights in technology and teacher education Chesapeake, VA: Association for the Advancement of Computing in Education (2009)

18. P. Scott, C. Jewitt, Talk, action and visual communication in teaching and learning science, School Science Review, 84 (308), 117-124 (2003)

19. N. E. Kasatkina, T. K. Gradusova, T. A. Zhukova, E. A. Kagakina, O. M. Kolupaeva, G. G. Solodova, I. V. Timonina, Modern educational technologies in the educational process of higher education, Kemerovo, GOU "KRIRPO", 233-234 (2011)

20. G. K. Tashkeeva, D. K. Sadibekova, A. K. Sariev, To the question of practice-oriented training in high school, Bulletin of the Kazakh National pedagogical University 3 (55) 44-49 (2017)

21. V. A. Tomsinov, The Role of the University in the life of society, Ethnicity and law, 1 4-8 (2016)

22. Jo. Ritzen, A Chance for European Universities or: Avoiding the Looming University Crisis in Europe, Amsterdam, 9 (2009) 
23. T. I. Rudneva, V. V. Levchenko, N. V. Solovova, N. B. Strekalova, Methodological approaches to the study of problems in the field of professional pedagogy: monograph. Samara: publishing house "Samara UN-t", 164 (2013)

24. N. G. Mokshina, Practice-oriented approach to teaching pedagogical disciplines. Materials of the VIII international conference. Scientific Conf. Actual problems of pedagogy, Moscow: Buki-Vedi, 154-157 (2017)

25. L. Yu. Aisner, S. M. Trashkova, The Role of education in the formation of personality, Kazan science 10 126-128 (2017)

26. E. G. Surkova, The Essence of the concept of "personal growth" in modern psychology (system approach), Acmeology, 3 (51) 58-65 (2014)

27. N. A. Kopylova, Methodological approaches to the study of the problem of interaction and cooperation in pedagogical science, University news, Series of Humanitarian Sciences, 4(3), 202-209 (2013)

28. S. Kurbatova, L. Aisner, A. Rusakov, V. Naumkina, Ecological Postulates of the national environmental policy (on the example of the Russian Federation) E3S Web of Conf. Key Trends in Transportation Innovation (KTTI-2019) 15704023 (2020)

29. S. M. Kurbatova, L. Yu. Aisner, V. V. Naumkina, Some legal aspects of environmental engineering IOP Conf. Ser.: Earth Environ. Sci. 421072006 (2020)

30. S. M. Kurbatova, L. Yu. Aisner, V. V. Naumkina, Some aspects of the essence and legal regulation of agriculture digitalization as one of the priorities of modern state policy of agriculture development. IOP Conf. Ser.: Earth Environ. Sci. 315032021 (2019)

31. S. Kurbatova, V. Vlasov, L. Aisner, Impact of risks and threats on the region's food supply in the context of import substitution E3S Web of Conferences International Conference on Efficient Production and Processing (ICEPP-2020) 16101089 (2020)

32. E. A. Letyagina, E. V. Dadayan, A. N. Storozheva, Governmental support of environmental protection and reducing of the negative consequences of adverse effects on the environment of the Krasnoyarsk Region. IOP Conference Series: Earth and Environmental Science, 52053 (2019)

33. S. M. Trashkova, Information component of the problem of personality formation: socio-philosophical aspect, Eurasian legal journal 8 (123) 425-427 (2018). 